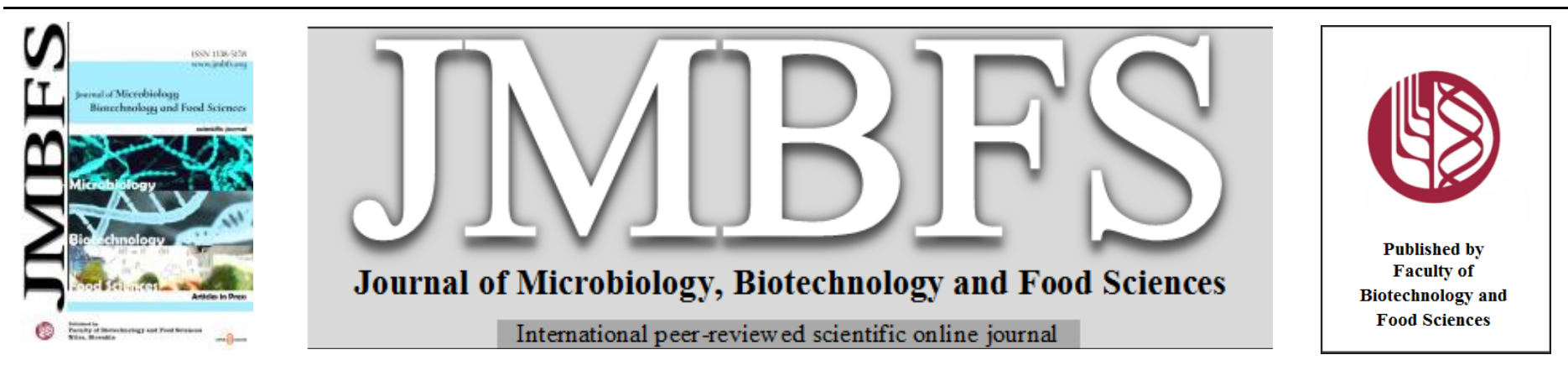

\title{
BARLEY BRAN, A NOVEL AGRICULTURAL WASTE FOR THE IMPROVED PRODUCTION OF AN EXTRACELLULAR LACCASE FROM A SOIL-INHABITED Penicillium spp.
}

\author{
Farah Javed ${ }^{l}$,Zeshan Ali *2, Sikander Ali ${ }^{1}$, Naveed Ahmed $^{3}$, Mirza Khursheed Alam ${ }^{1}$, Yasar Mahmood ${ }^{4}$ and Asif Wali ${ }^{5}$
}

\section{Address(es):}

${ }^{1}$ Institute of Industrial Biotechnology (IIB), GC University, Lahore, Pakistan.

${ }^{2}$ Faculty of Human Nutrition and Dietetics, Barani institute of Sciences, Sahiwal, Punjab, Pakistan.

${ }^{3}$ Department of Medical Microbiology and Parasitology, School of Medical Sciences, Universiti Sains Malaysia, Kubang Kerian 16150, Kota Bharu, Kelantan, Malaysia ${ }^{4}$ Department of Statistics, GC University, Lahore, Punjab, Pakistan.

${ }^{5}$ Department of Agriculture and Food Technology, Karakoram International University, Gilgit, Pakistan.

*Corresponding author: Zeshan@baraniinstutuite.edu.pk

\section{ARTICLE INFO}

Received 24. 8. 2020

Revised 28. 2. 2022

Accepted 1. 3. 2022

Published 1. 8. 2022

Regular article OPEN $\partial$ ACCESS

\begin{abstract}
Laccases are useful for bioleaching and removal of phenolics and xenobiotics. They play an important role in food, paper, pulp and textile industry. Laccases are very interesting biocatalysts for several industrial applications. The present research work was concerned with the production of an extracellular laccase from Penicillium spp. isolate IIB-11 on barley bran using solid state fermentation (SSF). The enzyme has various industrial applications such as in pulp and paper industry, textile industry, organic synthesis, bioremediation, food industry, pharmaceuticals and nano-biotechnology. Isolation of Penicillium was carried out from soil samples. The highest production $\left(2.94 \mathrm{Ug}^{-1}\right)$ was observed by Penicillium spp. isolate IIB-11. Different parameters were undertaken for optimization conditions. The highest enzyme activity $\left(36.29 \mathrm{Ug}^{-1}\right)$ from Penicillium spp. IIB-11 was observed using $50 \mathrm{~g}$ barley bran, $75 \mathrm{ml}$ of $\mathrm{HCl}(0.1 \mathrm{~N}), \mathrm{pH} 1.5,30^{\circ} \mathrm{C}$ temperature, $44 \mathrm{~h}$ time of incubation and $4 \%$ inoculum size. The enzyme activity was checked with copper sulphate and riboflavin. Maximum enzyme activity $\left(41.36 \mathrm{Ug}^{-1}\right)$ was obtained when $0.03 \%$ copper sulphate was used. The enzyme activity was also observed $\left(43.04 \mathrm{Ug}^{-1}\right)$ with riboflavin. Barley bran showed significant production of laccase $(p<0.05)$ with optimal conditions of the temperature, $\mathrm{pH}$, moisture content, $\mathrm{HCl}(0.1 \mathrm{~N})$ as a moistening agent and age of fungus. However, there is a need of further work on biochemical characterization and enzyme stability to scale up studies.
\end{abstract}

Keywords: Barley bran; Penicillium spp. (Soil-inhabited); Laccase; Solid state fermentation

\section{INTRODUCTION}

Laccase (benzenediol: oxygen oxidoreductase, EC 1.10.3.2) belongs to polyphenol oxidases category having 15-30\% carbohydrate contents (Couto and TocaHerrera, 2007). The enzyme contains copper atoms in catalytic site. The enzyme is very important because it oxidizes both the toxic and non-toxic substances (Shekher et al., 2011). The enzyme catalyzes the oxidation of substrates, such as mono, di and polyphenols, aminophenols, methoxyphenols and ascorbate. In laccase-based catalysis the reduction of oxygen occurs to water with oxidation of substrate. The oxygen-centered free radical is produced by oxidation and converted to quinone. The enzyme catalyzes the non-phenolic substrates by mediators, a group of low molecular weight organic compounds (Gochev and Krastanov, 2007; Hasham et al., 2020). Laccases are useful for bioleaching and removal of phenolics and xenobiotics and play an important role in food, paper, pulp and textile industry. Laccases are very interesting biocatalysts for several industrial applications (Tariq et al., 2020; Tišma et al., 2012).

Laccase is produced by fungi Phanerochaete chryosporium (Viswanath et al., 2008), plants, bacteria such as Streptomyces lavendulae. In plants, laccase plays role in lignification process in plants and as delignification in fungi. Enzyme production is an increasing field of biotechnology. Submerged fermentation (SmF) and solid state fermentation (SSF) are two types of fermentation which are used for enzyme production (Elisashvili et al., 2008; Wahab et al.). The liquid medium abundant in nutrients is used in $\mathrm{SmF}$ for the growth of microbes. This technique has disadvantages of high cost and uneconomical. The growth of microbes on a solid material in the absence or near absence of free water in a process known as SSF (Couto and Toca-Herrera, 2007). Due to low energy requirements, low-cost technology, high product yield and easy down streaming, SSF is suitable method for the growth of filamentous fungi. Solid substrates play very important role in fermentation. In SSF, different types of substrates are used for enzyme production. The agricultural wastes such as wheat bran, sugarcane bagasse etc. are the single source of energy (Javed et al., 2020; Mishra et al., 2011). Use of barley bran as solid substrate in SSF is a promising strategy for laccase production because it is rich in nutrients for growth of microorganisms (Asrat and Girma, 2018).

Many agricultural wastes such as barley bran (Couto et al., 2002) and rice bran (Chawachart et al., 2004) were used previously. Xin and Geng (2011) reported the optimal fermentation time for the production of laccase was on day 7 and optimum incubation temperature was $30^{\circ} \mathrm{C}$ (Xin and Geng, 2011). Quaratino et al. conducted the maximum activity at $\mathrm{pH} 3.75$ (Quaratino et al., 2007). Galhaup et al. studied the effect of copper sulphate and found the maximum enzyme production (Galhaup et al., 2002). Dhawan and kuhad found the riboflavin stimulated laccase production by 2.5-6 fold of control (Dhawan and Kuhad, 2002). Wheat bran, barley bran, rice bran, banana peel and bagasse etc are produced worldwide. All these products are used for production of different commercially important metabolic enzymes. Laccase is an important class of polyphenol oxidase. Different techniques are being developed to enhance its production (Asgher $\boldsymbol{e t}$ al., 2006). The production of laccase from Penicillium spp. using barley bran was not promoted last years. Therefore, in the present study different strains of Penicillium spp. were isolated for laccase production under SSF. Different parameters were optimized in order to obtain the highest enzyme production. The studied parameters were level of barley bran, different diluents, time of incubation, temperature, level of distilled water as an extracting agent, age of fungus and size of inoculums, effect of copper and riboflavin on enzyme activity (Dhawan and Kuhad, 2002).

\section{MATERIALS AND METHODS}

The chemicals including phenol detached crystals (PDC), sodium acetate, copper sulphate, riboflavin and ampicillin were of analytical grade. These were procured from Acros (Belgium) and Fluka (Switzerland). Other chemicals and reagents were also of the highest possible purity.

\section{Isolation and Maintenance of Organism}

Penicillium spp. were isolated from soil samples, collected from GC University Lahore and surroundings in sterile polythene bags. The sampling was done several times under aseptic conditions in laminar air flow cabinet (Technico Scientific Supply, Lahore, Pakistan) to get maximum diversity of microorganisms. One gram of soil was dispensed in sterilized distilled water $(9 \mathrm{ml})$ and serially diluted up to $10^{-4}$ and $10^{-6}$. The diluted samples $(0.1 \mathrm{ml})$ were spread on solidified malt extract agar (MEA) plates containing the antibiotic, ampicillin $(0.4 \%)$. The plates were 
incubated (11-679-25C, Gallenkamp, England) at $30^{\circ} \mathrm{C}$ for 3-5 days. Among the different microbial colonies appeared on MEA plates, the Penicillium spp. were picked up and transferred on potato dextrose agar (PDA), pH 5.6, slopes. The cultural and identification characteristics of the isolates were examined. Subculturing was done after 2 weeks and regularly studied under a light microscope (XSZ-107BN, China) to avoid any contamination. The slant cultures were stored at $4^{\circ} \mathrm{C}$ in a cold cabinet (MPR-1410, Sanyo, Japan).

\section{Inoculum Preparation and Cell Count}

The sterilized distilled water $(10 \mathrm{ml})$ was added to a slant culture (3-5 day old) aseptically. An inoculating wire loop was used to break down the clumps of spores. A homogenous suspension was obtained by gently shaking the tube. The spore count was done using haemocytometer (Marienfield, Germany) and found to be $2.15 \times 10^{7} \mathrm{CFUml}^{-1}$ (Aberkane et al., 2002).

\section{Solid Substrate}

For batch culture studies, Barley bran, a solid substrate, was purchased from local market of Lahore. The substrate was crushed twice in an electric grinder to obtain medium size particles $(2 \mathrm{~mm})$. The substrate was stored in sterile plastic bags under dry conditions until further used.

\section{Solid State Fermentation (SSF) Technique}

Fifty grams of barley bran as a solid substrate was taken in a $250 \mathrm{ml}$ Erlenmeyer flask. It was moistened by $75 \mathrm{ml}$ of $0.1 \mathrm{~N} \mathrm{HCl}$ and autoclaved (KT-40L, ALP Co Ltd., Tokyo, Japan) at $15 \mathrm{lbsin}^{-2}$ pressure at $121^{\circ} \mathrm{C}$ for $15 \mathrm{~min}$. The medium was cooled at room temperature $\left(25^{\circ} \mathrm{C}\right) .1 \mathrm{ml}$ of spore suspension was seeded as an inoculum, aseptically. The flask was gently shaken twice a day till the termination of batch culturing. The incubation was carried out at $30^{\circ} \mathrm{C}$ for $48 \mathrm{~h}$. Three parallel replicates were used for all batch culture experiments.

\section{Enzyme Extraction}

After incubation, $100 \mathrm{ml}$ of distilled water as an extracting agent was added to the flask containing fermented mash culture. A shaking incubator (VS-8480, Vision Sentific Co. Ltd.) at 200rpm for $1 \mathrm{~h}$ was used for the thoroughly mixing of contents in flask. The mixture was centrifuged (D-78532, Hettich Zentrifugen EBA 20 , Tuttligen, Germany) at $715 \times g$ for $15 \mathrm{~min}$. For enzyme assay, the clear supernatant was collected. The extracted enzyme was stored at $4^{\circ} \mathrm{C}$ for $24 \mathrm{~h}$.

\section{Enzyme Assay}

Enzyme extract $(1 \mathrm{ml}), 50 \mathrm{mM}$ sodium acetate buffer, $\mathrm{pH} 5(0.5 \mathrm{ml})$ and $1 \mu \mathrm{M}$ PDC $(0.1 \mathrm{ml})$ were added in a glass cuvette. The total volume was made up to $3 \mathrm{ml}$ by adding $1.4 \mathrm{ml}$ of sterilized distilled water and was shaken the mixture gently. The incubation was done at $30^{\circ} \mathrm{C}$ for $1 \mathrm{~min}$. Absorbance was noted using a spectrophotometer (SP-300, Optima, Tokyo, Japan) at $470 \mathrm{~nm}$. A control containing $1 \mathrm{ml}$ of distilled water in place of enzyme extract and keeping other conditions $[(0.5 \mathrm{ml}$ of $50 \mathrm{mM}$ sodium acetate buffer $(\mathrm{pH} 5)$ and $0.1 \mathrm{ml}$ of $1 \mu \mathrm{M}$ $\mathrm{PDC}]$ same was also used in experiment. The amount of enzyme oxidizing $1 \mu \mathrm{mole}$ of PDC per minute under the defined assay conditions is defined as one unit of laccase activity.

The enzyme activity was expressed as unit per gram $\left(\mathrm{Ug}^{-1}\right)$ of substrate using the following relationship,

$$
\text { Laccase activity } U g^{-1}=\frac{\mathrm{A}_{470 \mathrm{~nm}} \times \mathrm{DF} \times \mathrm{V}_{1}}{\text { Substrate }(\mathrm{g})} \times \frac{V_{2}}{\Delta T}
$$

Where,

$$
\begin{aligned}
A_{470} \mathrm{~nm} & =\text { Value of absorbance taken at } 470 \mathrm{~nm} \\
\mathrm{DF} & =\text { Dilution factor } \\
\mathrm{V}_{1} & =3 \text { (Total volume of reaction mixture in a glass cuvette) } \\
V_{2} & =\text { Volume of extractant added } \\
\triangle \mathrm{T} & =\text { Time of incubation }
\end{aligned}
$$

\section{Metallurgical Microscopy}

The surface analysis of non-inoculated and inoculated barley bran with Penicillium spp. was carried out using metallurgical microscope (Leica Q-550IW). A small quantity of fermented barley bran (44hours) was dried at $60^{\circ} \mathrm{C}$ for $40 \mathrm{~min}$. Very thin particles were selected as sample for observation. Unfermented barley bran was also observed and treated as control.

\section{Optimization of cultural conditions}

\section{Effect of Barley Bran as a Substrate}

The level of barley bran was varied from $12.5-75 \mathrm{~g}$ and its effect on laccase production was examined under SSF.

\section{Effect of Different Moistening Agents}

Different moistening agents such as phosphate buffer ( $\mathrm{pH} 7.2), 0.1 \mathrm{~N} \mathrm{HCl}(\mathrm{pH} 1.5)$, saline water $(\mathrm{pH} 6.7)$ and distilled water $(\mathrm{pH} 7.3)$ were used at a level of $1: 1 . \mathrm{HCl}$ $(0.1 \mathrm{~N})$ was found to be optimal. The effect of different $\mathrm{pH}(1-3.5)$ was examined. Different moisture levels $(25-150 \mathrm{ml})$ were also evaluated for maximum enzyme production.

\section{Time of Incubation}

Batch culture fermentations were carried out for different time periods (12-120 h) to study their effect on the production of enzyme. Other conditions were kept at their optimal levels $\left(50 \mathrm{~g}\right.$ Barley bran, $75 \mathrm{ml}$ of $\mathrm{HCl}(0.1 \mathrm{~N}), \mathrm{pH} 1.5,30^{\circ} \mathrm{C}$ temperature).

\section{Incubation Temperature}

The effect of different temperature of incubation $\left(20-60^{\circ} \mathrm{C}\right)$ was examined to derive the suitable temperature for the enzyme production.

\section{Effect of Enzyme Extraction at Various Level of Distilled Water}

Different levels of distilled water were studied for extraction which ranging from $50-300 \mathrm{ml}$. All batch culture experiments were conducted at optimal levels $(50 \mathrm{~g}$ barley bran, $75 \mathrm{ml}$ of $\mathrm{HCl}(0.1 \mathrm{~N}), \mathrm{pH} 1.5,30^{\circ} \mathrm{C}$ temperature, $44 \mathrm{~h}$ time of incubation).

\section{Size and Age of Inoculum}

The effect of age of fungus (3-18 days) and various inoculum levels (1-6\%) were evaluated for laccase production.

\section{Effect of Copper Sulphate and Riboflavin}

The effect of different concentrations of copper sulphate $(0.015 \%$ to $0.06 \%)$ and riboflavin $(0.005 \%$ to $0.02 \%)$ was examined for maximum enzyme production under SSF.

\section{Statistical Analysis}

The protected least difference method (Spss-21, version-4, USA) after Snedecor and Cochran (1980) was used to compare the treatment effects. The Duncan's multiple ranges in the form of probability (p) value was used to check the difference among the replicates.

\section{RESULTS AND DISCUSSION}

\section{Screening of Penicillium Isolates}

Twelve different strains of Penicillium were isolated from different samples of soil Screening of these species was done in order to find out the most productive strain for extracellular laccase under batch culture using solid state fermentation (SSF) technique. Some of the strains (IIB-1, IIB-4, IIB-6 and IIB-12) showed a very poor production i.e., $0.32,0.07,0.43$ and $0.66 \mathrm{Ug}^{-1}$, respectively. However, production $\left(1.77 \mathrm{Ug}^{-1}\right)$ from some other strains (IIB-9) was quite encouraging $(p<0.05)$. A marked increase of $2.94 \mathrm{Ug}^{-1}$ (LSD 1.215, Df 24) in enzyme production was observed with IIB-11. Therefore, isolate IIB-11 was used to obtain the highest enzyme production throughout batch culturing. Isolate of present study showed more enzyme production as compared to Pant and Adholeya (Pant and Adholeya, 2007) studies. They isolated the microorganisms such as Aspergillus flavus TERI DB9, Pleurotus. ostreatus (Florida) EM 1303 from soil and effluent for enzyme production. Enzyme production by these organisms was $0.45 \mathrm{Ug}^{-1}$ and $0.81 \mathrm{Ug}^{-1}$, respectively. Chen et al. isolated 20 fungi from sea mud, sea grass and mangrove samples (Chen $\boldsymbol{e t}$ al., 2011). Among those isolates, 63, showed maximum enzyme activity.

\section{Level of barley Bran as a Solid Substrate}

The level of substrate has great influence on the production of enzyme by Penicillium spp. IIB-11 in solid state fermentation (SSF) (Figure 1). Barley bran was used as a solid substrate and different levels $(12.5,25,37.5,50,62.5$ and 75 $\mathrm{g}$ ) were employed to obtain the highest enzyme production. An enzyme production of $0.72 \mathrm{Ug}^{-1}$ was obtained when $12.5 \mathrm{~g}$ barley bran was used. The enzyme 
production was increased ( 1.36 to $2.02 \mathrm{Ug}^{-1}$ ) when the level of substrate was enhanced from 25-37.5 g. Maximum enzyme production of $2.82 \mathrm{Ug}^{-1}$ (LSD 1.419, Df 12) was achieved at $50 \mathrm{~g}$ of substrate. Enzyme activity $\left(1.53 \mathrm{Ug}^{-1}\right)$ was markedly declined $(p<0.05)$ at $75 \mathrm{~g}$ of substrate.

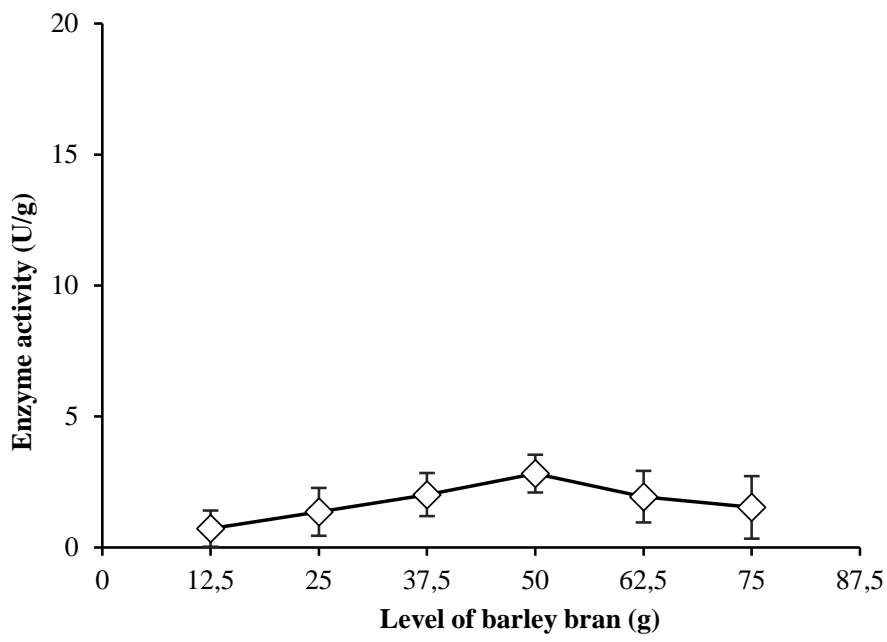

Figure 1 Effect of different levels of barley bran as a substrate on the production of an extracellular laccase from Penicillium spp. IIB-11 under SSF.

The solid substrate used for SSF is an important because it serves as an anchorage for microbial cells, provides nutrients and an appropriate level of biomass generation for fermentation (Vivekanand et al., 2011). Rosales et al. studied the enzyme production using barley bran (Rosales $\boldsymbol{e}$ t al., 2002). The maximum enzyme activity $\left(22.47 \mathrm{Ul}^{-1}\right)$ was shown on $8^{\text {th }}$ day of incubation. The volatile compounds produced by fungal metabolism, waste conversion into volatile compounds was produced which are used in reduction of dry mass during fungal fermentation. Lignino-cellulolytic enzyme production was mainly affected by the strain, substrate composition and culture conditions (Iandolo et al., 2011) Chawachart et al. studied the enzyme production by thermotolerant basidiomycetes on barley bran (Chawachart et al., 2004). Different levels of barley bran were employed to obtain maximum enzyme activity. A very low production was observed at a low level of substrate. However, there was a gradua increase in the production with increase in the level of barley bran. Maximum enzyme production $\left(2.82 \mathrm{Ug}^{-1}\right)$ was obtained with $50 \mathrm{~g}$ of the substrate due to presence of optimal level of growth nutrients.

\section{Effect of Different Diluents}

Different diluents (saline water $\mathrm{pH}$ 6.7, distilled water $\mathrm{pH} 7.3, \mathrm{HCl}(0.1 \mathrm{~N}) \mathrm{pH} 1.5$ and phosphate buffer $\mathrm{pH} 7.2$ ) were studied to check their effects on laccase production of Penicillium spp. IIB-11 (Figure 2). The less activity (2.12 and 2.98 $\mathrm{Ug}^{-1}$ ) was observed with saline water and distilled water, respectively. A significant higher activity of $6.32 \mathrm{Ug}^{-1}$ (LSD 2.299, Df 8, $p<0.05$ ) was obtained with $\mathrm{HCl}(0.1 \mathrm{~N})$. Enzyme activity was declined to $3.76 \mathrm{Ug}^{-1}$ with phosphate buffer, $\mathrm{pH} 7.2$.

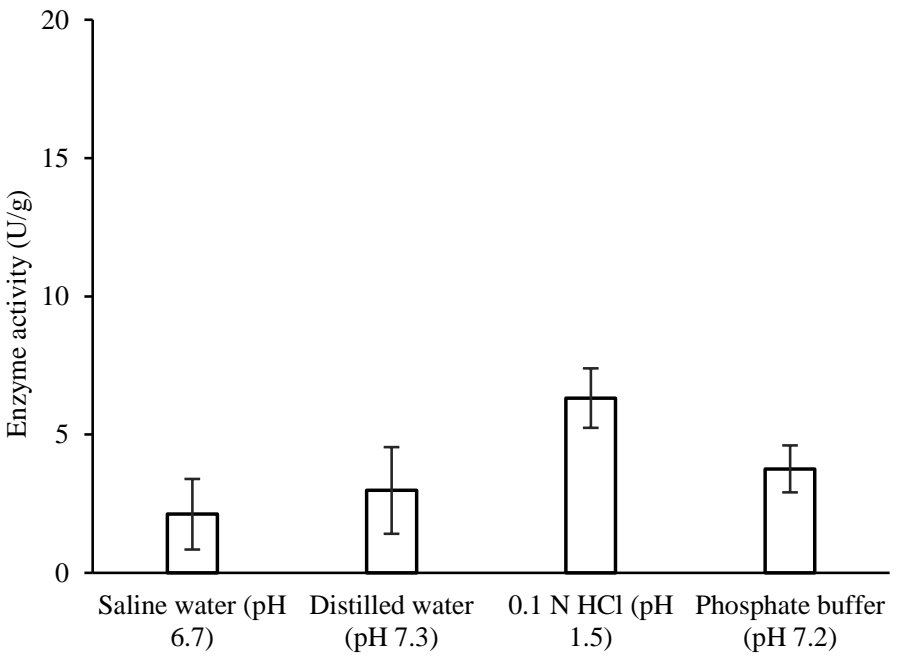

Different diluents

Figure 2 Effect of different diluents on the production of an extracellular laccase from Penicillium Spp. IIB-11 under SSF.

The diluents were added at 1:1 level with substrate. The maximum enzyme production $\left(6.32 \mathrm{Ug}^{-1}\right)$ was obtained with $0.1 \mathrm{~N} \mathrm{HCl}$. The addition of correct proportion of nutrients in solid substrate was the reason for the enhancement of enzyme production. Pant and Adholeya were used four different diluents viz., water, $1 \%$ molasses, $100 \%$ distillery effluent and Potato dextrose broth (PDB) to check their effect and suitability for enhancing fungal growth and enzyme production (Pant and Adholeya, 2007). They found maximum enzyme production in Aspergillus flavus TERI DB9 with effluent as a diluent. Pleurotus osttreatus EM 1303 was reported for maximum enzyme production on corncob with molasses as a moistening agent.

The effect of different $\mathrm{pH}$ of $\mathrm{HCl}(0.1 \mathrm{~N})$ on enzyme activity from Penicillium spp. IIB-11 was recorded (Figure 3). pH was adjusted between 1-3.5. The lowest activity $\left(3.96 \mathrm{Ug}^{-1}\right)$ was observed, when $\mathrm{pH}$ was adjusted to 1 . A marked increase of $6.4 \mathrm{U} / \mathrm{g}$ (LSD 2.135, Df 12, $p<0.05$ ) in the activity was noted at $\mathrm{pH} 1.5$. There was a gradual reduction in the activity up to $0.98 \mathrm{Ug}^{-1}$ with increase in the $\mathrm{pH}(2$ $3.5)$.

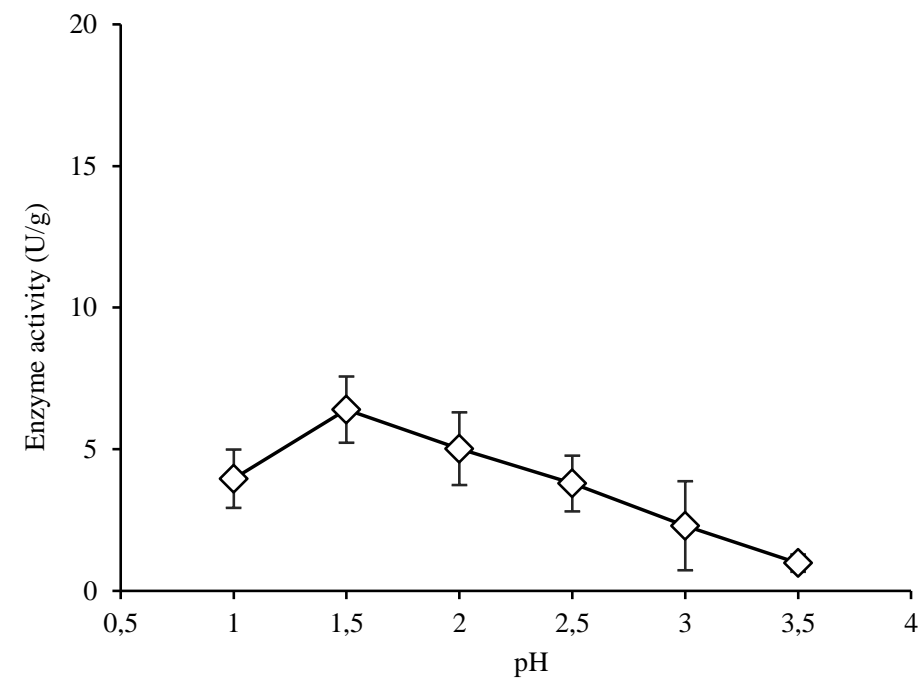

Figure 3 Effect of different $\mathrm{pH}$ of diluent on the production of an extracellular laccase from Penicillium spp. IIB-11 under SSF.

The increase or decrease in $\mathrm{pH}$ from optimum value results the poor growth of microbes. During fermentation organic acids are produced due to which $\mathrm{pH}$ of media are changed (Ertan et al., 2006). Each microorganism is a pH specific for normal growth and metabolic activity (Xin and Geng, 2011). The enzyme stability as a function of $\mathrm{pH}$ was detected at different values and optimum $\mathrm{pH}$ was 3.75 (DMP as a substrate) as reported by Quaratino et al. (Quaratino et al., 2007). Chen et al. studied the enzyme production at optimal $\mathrm{pH}$ of 5 by Pestalotiopsis sp. $\mathrm{j} 63$ (Chen et al., 2011). It is useful to maintain high level of enzyme activity and its stability. Strain $\mathrm{j} 63$ can only adapt to a mild acidic condition.

The production of enzyme by Penicillium spp. IIB-11 in solid state fermentation (SSF) is greatly influenced by the level of diluent (Figure 4). Different levels of $0.1 \mathrm{~N} \mathrm{HCl}(25,50,75,100,125$ and $150 \mathrm{ml})$ were employed to obtain the highest production of laccase. An enzyme production $\left(4.6 \mathrm{Ug}^{-1}\right)$ was obtained with $25 \mathrm{ml}$ $\mathrm{HCl}(0.1 \mathrm{~N})$. Maximum enzyme activity of $17.6 \mathrm{Ug}^{-1}$ (LSD 2.735, Df 12) was achieved at $75 \mathrm{ml}$ of diluent. A gradual decrease in enzyme activity was observed (12.2 to $7.78 \mathrm{Ug}^{-1}$ ) as the level of diluent was further increased from $100-150 \mathrm{ml}$.

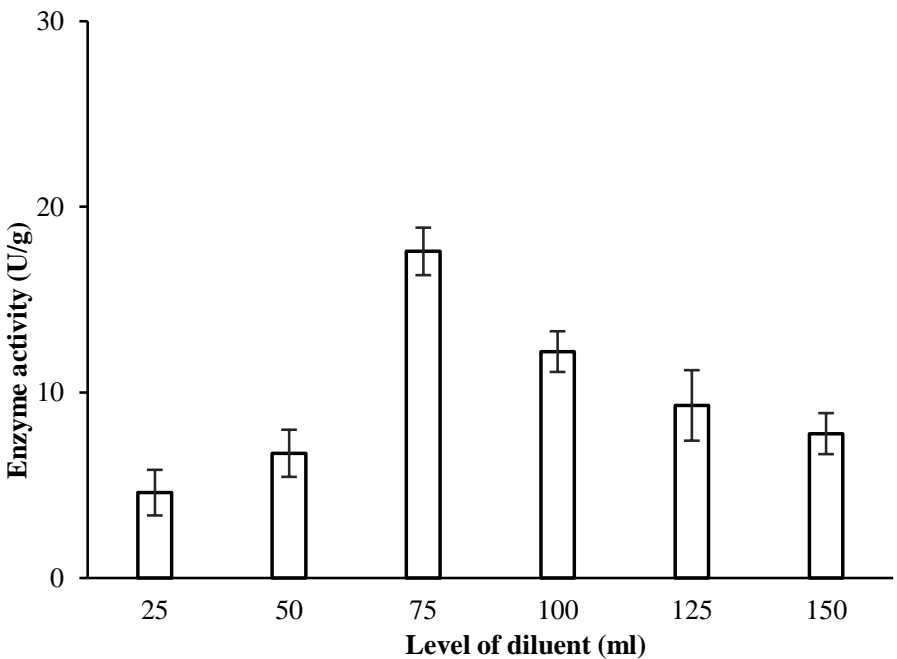

Figure 4 Effect of different levels of diluent on the production of an extracellular laccase from Penicillium spp. IIB-11 under SSF. 
Under optimal moisture levels, growth, enzyme stability, and secretion are affected. Higher moisture levels lead to particle accumulation, gas transfer limitations, and bacterial competition (Xin and Geng, 2011). They reported maximum enzyme production $\left(8.6 \mathrm{Ug}^{-1}\right)$ with $85-90 \%$ of diluent level. In SSF, moisture level influences laccase production by interfering with the physical properties of solid particles. Increased moisture levels reduce the porosity of substrates and also limit oxygen transfer (Vivekanand et al., 2011). The amount of moisture affecting SSF is crucial for new cell synthesis, growth, and enzyme production. It also affects the utilization of substrates and the production of laccase (Revankar et al., 2007). When diluent levels decrease, fungi are unable to acquire nutrients from the media. In the present study, $75 \mathrm{~mL}$ of diluent were used for enzyme production, which is in agreement with Pant and Adholeya's findings (Pant and Adholeya, 2007)

\section{Time of Incubation}

The rate of laccase production from Penicillium spp. IIB-11 in SSF was studied for maximum enzyme production (Figure 5). Different time of incubation (12, 24, 28 , $32,36,40,44,48,60,72,84,96,108$ and $120 \mathrm{~h}$ ) was examined after inoculation. Initially at $12 \mathrm{~h}$ of incubation, $\left(0.42 \mathrm{Ug}^{-1}\right)$ enzyme activity was found. Enzyme production was increased gradually with the increase in the incubation period from $24-40 \mathrm{~h}$. However, the best results in terms of enzyme production $(p<0.05)$ were achieved at an incubation period of 44h. The enzyme production was recorded to a maximal of $26.06 \mathrm{Ug}^{-1}$ (LSD 1.743, Df 28). Afterwards, the enzyme production declined gradually (48-120 h) up to $2.06 \mathrm{Ug}^{-1}$.

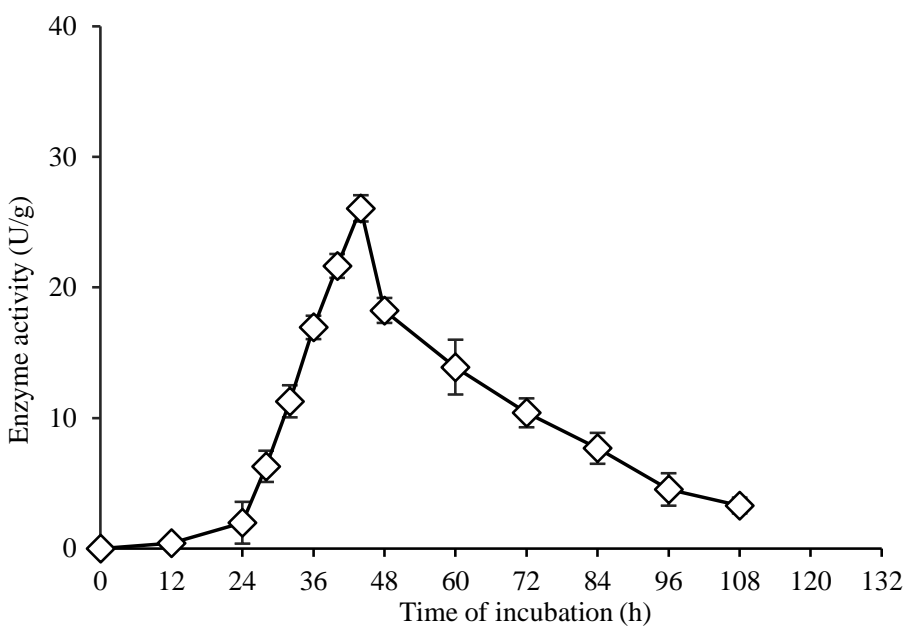

Figure 5 Effect of different time of incubation on the production of an extracellular laccase from Penicillium spp. IIB-11 under SSF.

For a given culture, the optimal incubation time is determined by the growth rate and enzyme production as well as the characteristics of the culture.]. The incubation time varies with enzyme productions (Palmieri et al., 2000). Vivekanand et al. detected the maximum enzyme production at $144 \mathrm{~h}$ of fermentation. In the beginning the enzyme production was low, later increased and then declined $(p<0.05)$. This increase was due to utilization of media and nutrients Eventually, there was a drop in enzyme production level on account of nutrient depletion and product accumulation (Vivekanand $\boldsymbol{e t}$ al., 2011). Xin and Geng reported $168 \mathrm{~h}$ for maximum enzyme production $\left(2.34 \mathrm{Ug}^{-1}\right)$ while in present results the maximum enzyme production $\left(26.06 \mathrm{Ug}^{-1}\right)$ was at $44 \mathrm{~h}$ of fermentation (Xin and Geng, 2011).

\section{Effect of Temperature}

Influence of incubation temperature $\left(20,25,30,35,40,45\right.$ and $\left.50^{\circ} \mathrm{C}\right)$ on laccase production from Penicillium spp. IIB-11 in SSF was investigated (Figure 6). The enzyme production was not encouraging at $20^{\circ} \mathrm{C}\left(23.33 \mathrm{Ug}^{-1}\right)$. A better enzyme yield was however noticed $28.03 \mathrm{Ug}^{-1}$ (LSD 2.214, Df 14) when the temperature was adjusted to $30^{\circ} \mathrm{C}$, throughout the fermentation period of $44 \mathrm{~h}$. As the temperature was increased $\left(35-45^{\circ} \mathrm{C}\right)$, a decrease in enzyme production was observed. An enzyme production of $16.21 \mathrm{Ug}^{-1}$ was achieved when the temperature was raised to $50^{\circ} \mathrm{C}$.

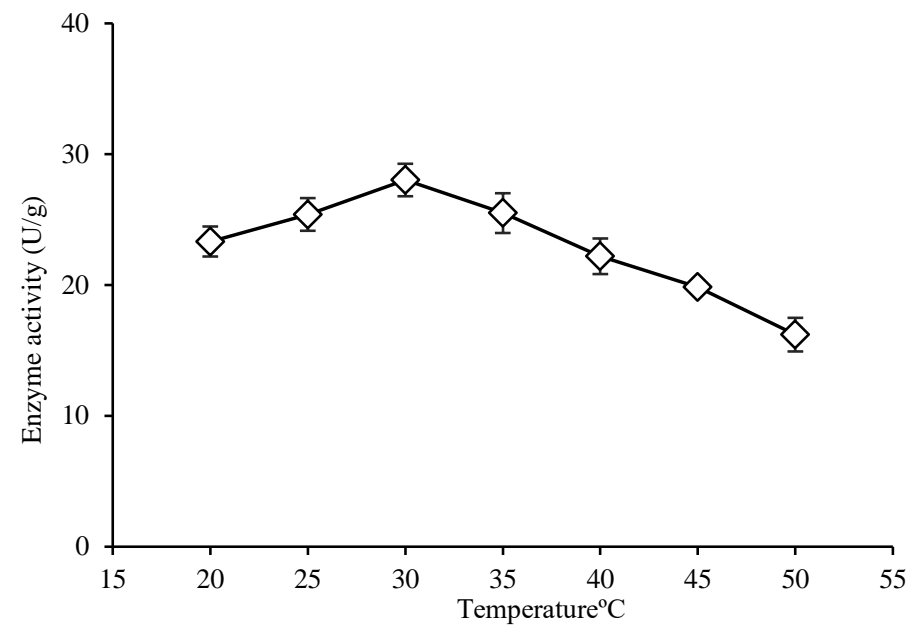

Figure 6 Effect of different temperatures on the production of an extracellular laccase from Penicillium spp. IIB-11 under SSF.

Temperature is very significant in SSF process as there is an increase in temperature of the fermented mass due to respiration (Prema et al., 2007). In addition to all physical factors affecting the SSF, temperature is the most influential. Cell growth, enzyme production, and metabolic reactions are sensitive to temperature (Xin and Geng, 2011). They found the maximum enzyme production $\left(1.6 \mathrm{Ug}^{-1}\right)$ at $30^{\circ} \mathrm{C}$ which was less from present study i.e., $28.03 \mathrm{Ug}^{-1}$. Higher temperature has some disadvantages as the effects on the metabolic activities of microorganisms by destroying their enzymes while metabolic activities of microbes are low at lower temperature. The control of temperature in SSF is very critical. Vivekanand et al. observed the enzyme production at $30^{\circ} \mathrm{C}$ as it reduced the rate of evaporation during the incubation (Vivekanand et al., 2011). The effect of temperature is an important factor in all fermentation techniques because of its impact on microbial growth and metabolite production (Niladevi $e t$ al., 2007).

\section{Level of Distilled Water as an Extracting Agent}

The production of enzyme by Penicillium spp. IIB-11 in solid state fermentation (SSF) is greatly influenced by the level of distilled water as an extracting agent (Figure 7). Different levels of distilled water (50, 100, 150, 200, 250 and $300 \mathrm{ml}$ ) were employed to obtain the highest production of laccase during extraction. An enzyme production $\left(19.26 \mathrm{Ug}^{-1}\right)$ was obtained when $50 \mathrm{ml}$ distilled water was used. Maximum enzyme activity of $29.02 \mathrm{Ug}^{-1}$ (LSD 2.817, Df 12) was achieved at 100 $\mathrm{ml}$ of distilled water. A gradual decrease in enzyme activity (20.32 to $7.34 \mathrm{Ug}^{-1}$, $p<0.05)$ was observed as the level of distilled water was further increased from 150-300 $\mathrm{ml}$, respectively.

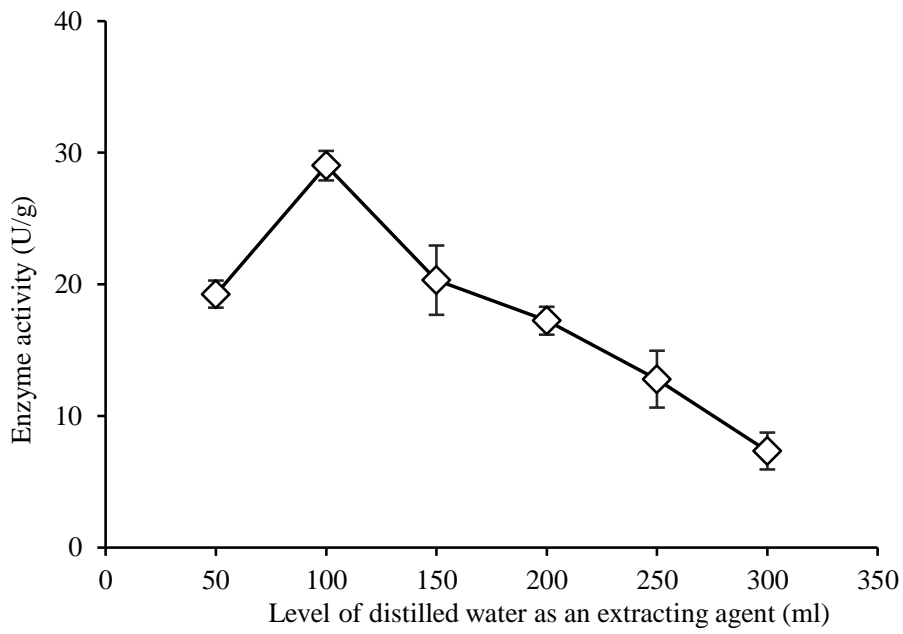

Figure 7 Enzyme extraction at various levels of distilled water produced by Penicillium spp. IIB-11 under SSF.

Maximum enzyme activity $\left(29.02 \mathrm{Ug}^{-1}\right)$ was achieved with $100 \mathrm{ml}$ of distilled water due to better interaction between the liquid and solid phases, laccase was better extracted under the specified conditions. Pant and Adholeya also used distilled water as an extracting agent for Aspergillus flavus (Pant and Adholeya, 2007). In disparity, they used buffer for Pleroutus ostreatus. 


\section{Age of Fungus and Size of Inoculum}

The effect of age of fungus (3, 6, 9, 12, 15 and 18 day) on laccase production from Penicillium spp. IIB-11 in SSF was studied. The enzyme production was not effective (6.31 to $\left.18.92 \mathrm{Ug}^{-1}\right)$ when 3-6 days old culture was used. However, the best results in terms of enzyme production $30.08 \mathrm{Ug}^{-1}$ (LSD 5.648, Df 12) were achieved at 9 days old culture. At the age of fungus higher than the optimal, the enzyme production was markedly declined and the lowest enzyme activity $(9.25$ $\left.\mathrm{Ug}^{-1}, p<0.05\right)$ was observed at 18 -day old culture.

The effect of size of inoculum $\left(1,2,3,4,5,6 \%, \mathrm{vv}^{-1}\right)$ on laccase production from Penicillium spp. IIB-11 in SSF was also studied (Figure 8). The enzyme production was not effective $\left(29.39 \mathrm{Ug}^{-1}\right)$ when $1 \%$ of spore culture was used to inoculate the sterile culture media. A gradual increase in enzyme activity (31.21 to $33.09 \mathrm{Ug}^{-1}$ ) was observed with 2 and $3 \%$ inoculum, respectively. Maximum enzyme activity of $36.29 \mathrm{Ug}^{-1}$ (LSD 2.966 , Df 12) was achieved at $4 \%$ of spore culture. At an inoculum size higher than the optimal, the enzyme production was markedly declined and the lowest enzyme activity $\left(23.24 \mathrm{Ug}^{-1}, p<0.05\right)$ was observed at $6 \%$ inoculum
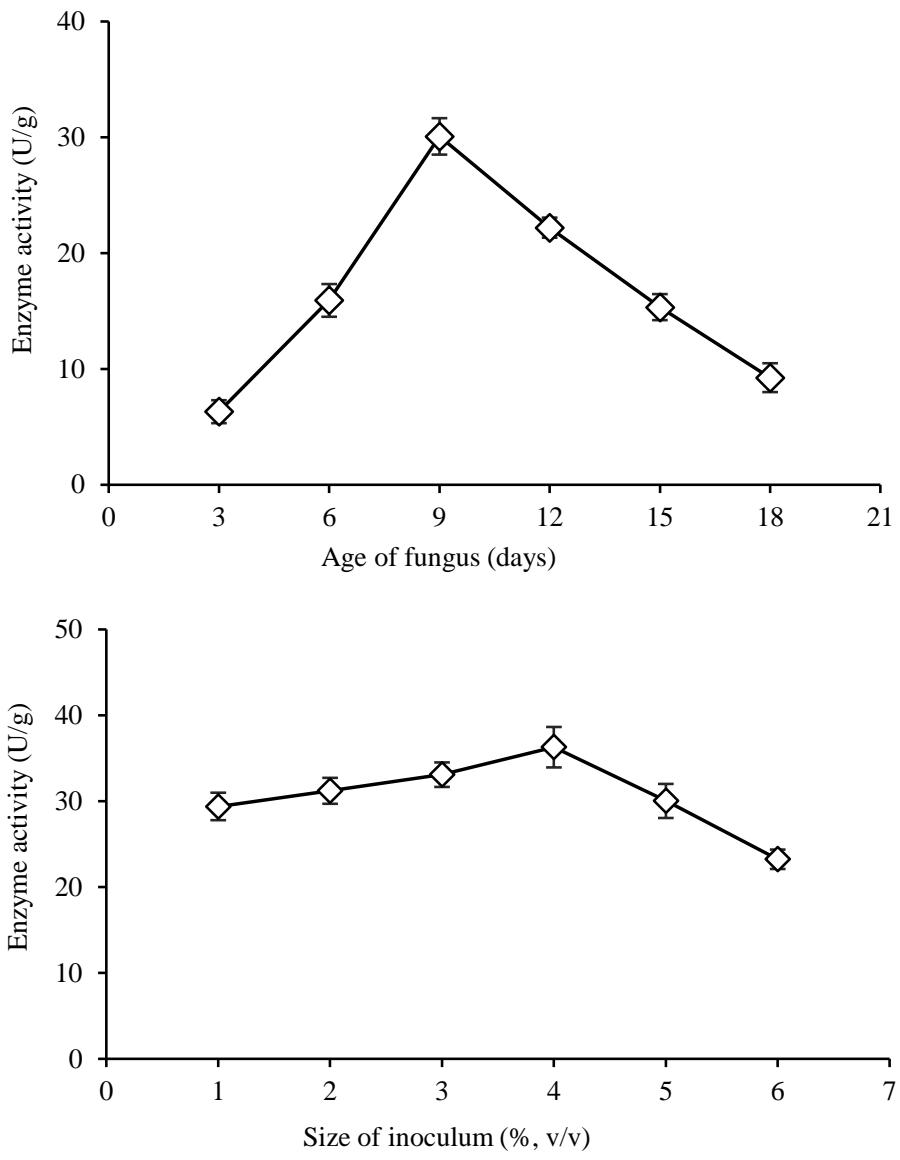

Figure 8 Effect of different age of fungus and different size of inoculum on the production of an extracellular laccase from Penicillium spp. IIB-11 under SSF.

SSF processes rely heavily on inoculum density. Higher inoculum levels inhibit fungal growth and enzyme production due to the increase in water content in the solid substrate. Lower inoculum levels, on the other hand, require longer fermentation times in SSF still cultures. SSF enzyme production is influenced by the size of the inoculum. Lower levels of inoculum may not be sufficient to initiate growth, whereas higher levels may inhibit it (Prema et al., 2007). Maximum enzyme activity was found to be $2,399 \mathrm{Ug}^{-1}$ of substrate. The reduced products are formed with low inoculum level because insufficient biomass is generated whereas excessive biomass is formed with high level of inoculum which drains out the substrate, essential for product formation (Vivekanand et al., 2011). They observed the maximum enzyme activity $\left(5945 \mathrm{Ul}^{-1}\right)$ using $6 \%$ inoculum. The maximum enzyme activity (36.29 $\mathrm{Ug}^{-1}$ ) was found in present study which was almost same as the findings of Niladevi et al. (Niladevi et al., 2007) i.e., $33.4 \mathrm{Ug}^{1}$.

\section{Effect of Copper Sulphate}

Different concentrations $\left(0.015,0.03,0.045\right.$ and $\left.0.06 \%, \mathrm{wv}^{-1}\right)$ of copper sulphate were tested to obtain highest yield. A control having no concentration of copper sulphate showed the enzyme activity of $35.92 \mathrm{Ug}^{-1}$. Barley bran supplemented with $0.015 \%$ of copper sulphate had enzyme activity of $36.05 \mathrm{Ug}^{-1}$. However, the optimum enzyme activity of $41.36 \mathrm{Ug}^{-1}$ (LSD 3.657, Df 10) was achieved at 0.03
$\%$ copper sulphate and it is higher than the activity of control. Concentrations higher than the optimal showed a decline in production $\left(31.38 \mathrm{Ug}^{-1}\right.$ at $\left.0.06 \%\right)$.

To increase the yield of ligninolytic enzyme, the medium is supplemented with inducers. The nature of inducers differs widely with species. Among the several laccase inducers are copper sulphate, veratryl alcohol, guaiacol, pyrogallol, synergic acid and alcohol (Xin and Geng, 2011). Copper sulphate is one of the widely reported inducer of laccases in many fungi (Galhaup et al., 2002; Palmieri et al., 2000). Galhaup et al. (Galhaup et al., 2002) studied the effect of copper sulphate and found the maximum enzyme production $\left(15.74 \mathrm{kUl}^{-1}\right)$ while in present study, the enzyme production was $41.36 \mathrm{Ug}^{-1}$. Baldrian (Baldrian, 2003) found the maximum activity (411 $\mathrm{IUml}^{-1}$ ) with $0.5 \mathrm{mM}$ copper sulphate. Laccase is a copper containing enzyme. Therefore, copper ion in the medium plays important role in forming a metal active site.

\section{Effect of Riboflavin}

Different concentrations $\left(0.005,0.01,0.015\right.$ and $\left.0.02 \%, \mathrm{wv}^{-1}\right)$ of riboflavin were employed to find out maximal production (Figure 9). A control having no concentration of riboflavin showed the enzyme activity of $40.32 \mathrm{Ug}^{-1}$. A gradual increase in enzyme activity (34.01 to $42.01 \mathrm{Ug}^{-1}$ ) was observed with 0.005 to 0.015 $\%$ riboflavin. However, the maximum enzyme production of $43.04 \mathrm{Ug}^{-1}$ (LSD 4.266, Df 10) was obtained at $0.02 \%$ of riboflavin
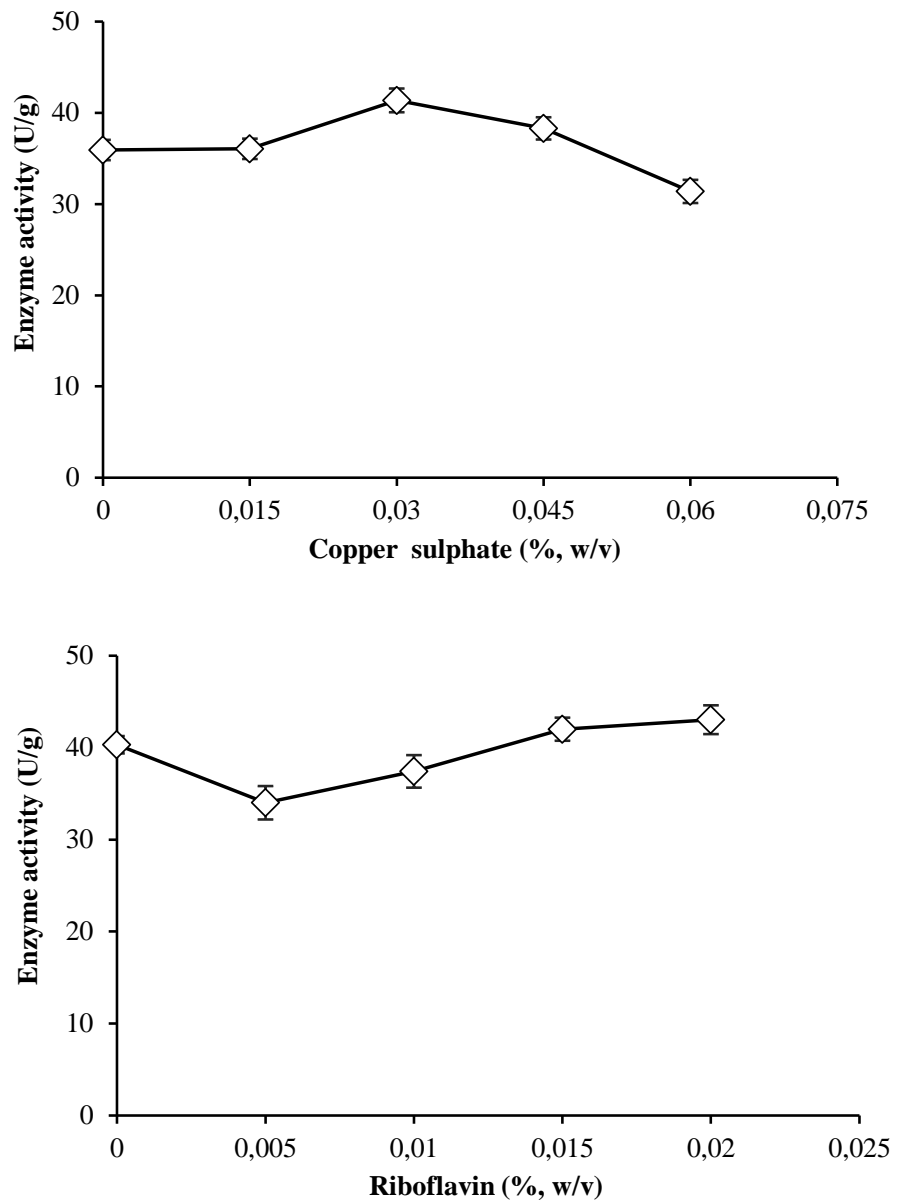

Figure 9 Effect of different concentrations of copper sulphate and different concentrations of riboflavin on laccase activity of Penicillium spp. IIB-11 under SSF.

Dhawan and kuhad found the riboflavin stimulated laccase production by 2.5-6 fold of control (Dhawan and Kuhad, 2002). The increase in enzyme activity was because of alteration of membrane permeability, exocytosis, enzyme stabilization and structural changes of molecule itself. The maximum enzyme production (43.04 $\mathrm{Ug}^{-1}$ ) using $0.02 \%$ riboflavin was observed in present studies.

\section{CONCLUSION}

The procedure for the production of an extracellular laccase from a soil-inhabited Penicillium spp. IIB-11 was conducted under solid state fermentation (SSF) Barley bran as a solid substrate showed significant production $(p<0.05)$ with HC $(0.1 \mathrm{~N})$ as a moistening agent. Different parameters including temperature, $\mathrm{pH}$, moisture content and age of fungus exhibited maximum production at $30^{\circ} \mathrm{C}, 1.5$, $75 \mathrm{ml}$ and 9 days, respectively. The enzyme production was markedly increased $(p<0.05)$ at $4 \%$ inoculum in $44 \mathrm{~h}$. Copper sulphate and riboflavin were used for 
determination of enzyme activity. However, further work on biochemical characterization and enzyme stability is required to scale up studies

Acknowledgments: Vice chancellor and director of IIB, GCU are gratefully acknowledged for their cooperation and help.

\section{REFERENCES}

Aberkane, A., M. Cuenca-Estrella, A. Gomez-Lopez, E. Petrikkou, E. Mellado, A Monzon, and J. Rodriguez-Tudela. 2002. Comparative evaluation of two different methods of inoculum preparation for antifungal susceptibility testing of filamentous fungi. J Antimicrob Chemother. 50:719-722. https://doi.org/10.1093/jac/dkf187

Asgher, M., M. Asad, and R. Legge. 2006. Enhanced lignin peroxidase synthesis by Phanerochaete chrysosporium in solid state bioprocessing of a lignocellulosic substrate. World J Microbiolog Biotechnolog. 22:449-453. https://doi.org/10.1007/s11274-005-9055-7

Asrat, B., and A. Girma. 2018. Isolation, production and characterization of amylase enzyme using the isolate Aspergillus niger FAB-211. Int J Biotechnolog Molec Biolog Res. 9:7-14. https://doi.org/10.5897/IJBMBR2018.0289

Baldrian, P. 2003. Interactions of heavy metals with white-rot fungi. Enz Microb technolog. 32:78-91. https://doi.org/10.1016/S0141-0229(02)00245-4

Chawachart, N., C. Khanongnuch, T. Watanabe, and S. Lumyong. 2004. Rice bran as an efficient substrate for laccase production from thermotolerant basidiomycete Coriolus versicolor strain RC3. Fung Div. 15:23-32.

Chen, H.-Y., D.-S. Xue, X.-Y. Feng, and S.-J. Yao. 2011. Screening and production of ligninolytic enzyme by a marine-derived fungal Pestalotiopsis sp J63. Appl biochem biotechnolog. 165:1754-1769. https://doi.org/10.1007/s12010011-9392-y

Couto, S.R., and J.L. Toca-Herrera. 2007. Laccase production at reactor scale by $\begin{array}{llll}\text { filamentous fungi. } & \text { Biotechnolog adv. }\end{array}$ https://doi.org/10.1016/j.biotechadv.2007.07.002

Couto, S.R.g., M.a. Gundín, M. Lorenzo, and M.Á. Sanromán. 2002. Screening of supports and inducers for laccase production by Trametes versicolor in semi-solidstate conditions. Proc Biochem. 38:249-255. https://doi.org/10.1016/S0032 9592(02)00087-0

Dhawan, S., and R.C. Kuhad. 2002. Effect of amino acids and vitamins on laccase production by the bird's nest fungus Cyathus bulleri. Biores Technolog. 84:35-38 https://doi.org/10.1016/S0960-8524(02)00026-3

Elisashvili, V., E. Kachlishvili, and M. Penninckx. 2008. Effect of growth substrate, method of fermentation, and nitrogen source on lignocellulosedegrading enzymes production by white-rot basidiomycetes. J indust microbiolog biotechnolog. 35:1531-1538. https://doi.org/10.1007/s10295-008-0454-2

Ertan, F., B. Balkan, S. Balkan, and T. Aktac. 2006. Solid state fermentation for the production of $\alpha$-amylase from Penicillium chrysogenum using mixed agricultural by-products as substrate. Biologia. 61:657-661. https://doi.org/10.2478/s11756-006-0137-2

Galhaup, C., H. Wagner, B. Hinterstoisser, and D. Haltrich. 2002. Increased production of laccase by the wood-degrading basidiomycete Trametes pubescens Enz Microb Technolog. 30:529-536. https://doi.org/10.1016/S0141 0229(01)00522-1

Gochev, V., and A. Krastanov. 2007. Fungal laccases. Bulgarian J Agr Sci. 13:75 Hasham, K., N. Ahmed, and B. Zeshan. 2020. Circulating microRNAs in oncogenic viral infections: potential diagnostic biomarkers. SN Appl Sci. 2:1-13 https://doi.org/10.1007/s42452-020-2251-0

Iandolo, D., A. Piscitelli, G. Sannia, and V. Faraco. 2011. Enzyme production by solid substrate fermentation of Pleurotus ostreatus and Trametes versicolor on tomato pomace. App biochem biotechnolog. 163:40-51 https://doi.org/10.1007/s12010-010-9014-0

Javed, F., Z. Ali, S. Iqbal, N. Ahmed, Z. Farooq, F. Masood, and M. Nawaz. 2020 Production of synbiotic product containing galacto-oligosaccharides and Saccharomyces boulardii and evaluation of its in-vitro bifidogenic effect. Journal of Microbiology, Biotechnolog Food Sci. 2020:197-200. https://doi.org/10.15414/jmbfs.2020.10.2.197-200

Mishra, A., S. Kumar, and A.K. Pandey. 2011. Laccase production and simultaneous decolorization of synthetic dyes in unique inexpensive medium by new isolates of white rot fungus. Int Biodeter Biodegrad. 65:487-493. https://doi.org/10.1016/j.ibiod.2011.01.011

Niladevi, K.N., R.K. Sukumaran, and P. Prema. 2007. Utilization of rice straw for laccase production by Streptomyces psammoticus in solid-state fermentation. J ind microbiolog biotechnolog. 34:665-674. https://doi.org/10.1007/s10295-007-0239-

Palmieri, G., P. Giardina, C. Bianco, B. Fontanella, and G. Sannia. 2000. Copper induction of laccase isoenzymes in the ligninolytic fungus Pleurotus ostreatus. App environ microbiolog. 66:920-924. https://doi.org/10.1128/AEM.66.3.920$\underline{924.2000}$

Pant, D., and A. Adholeya. 2007. Enhanced production of ligninolytic enzymes and decolorization of molasses distillery wastewater by fungi under solid state fermentation. Biodegrad. 18:647-659. https://doi.org/10.1007/s10532-006-9097-Z
Prema, P., K. Niladevi, and R.K. Sukumaran. 2007. Utilization of rice straw for laccase production by Streptomyces psammoticus in solid-state fermentation.

Quaratino, D., F. Federici, M. Petruccioli, M. Fenice, and A. D’Annibale. 2007. Production, purification and partial characterisation of a novel laccase from the white-rot fungus Panus tigrinus CBS 577.79. Antonie van Leeuwenhoek. 91:5769. https://doi.org/10.1007/s10482-006-9096-4

Revankar, M.S., K.M. Desai, and S. Lele. 2007. Solid-state fermentation for enhanced production of laccase using indigenously isolated Ganoderma sp. Appl biochem biotechnolog. 143:16-26. https://doi.org/10.1007/s12010-007-0029-0

Rosales, E., S.R. Couto, and A. Sanromán. 2002. New uses of food waste: application to laccase production by Trametes hirsuta. Biotechnolog Let. 24:701 704. https://doi.org/10.1023/A:1015234100459

Shekher, R., S. Sehgal, M. Kamthania, and A. Kumar. 2011. Laccase: microbial sources, production, purification, and potential biotechnological applications. Enz res. 2011.

Tariq, F., N. Ahmed, M. Afzal, M.A.U. Khan, and B. Zeshan. 2020. Synthesis, Characterization and Antimicrobial Activity of Bacillus subtilis-Derived Silver Nanoparticles Against Multidrug-Resistant Bacteria. Jund J Microbiolog. 13 https://doi.org/10.5812/jjm.91934

Tišma, M., P. Žnidaršič-Plazl, Đ. Vasić-Rački, and B. Zelić. 2012. Optimization of laccase production by Trametes versicolor cultivated on industrial waste. App biochem biotechnolog. 166:36-46. https://doi.org/10.1007/s12010-011-9401-1

Viswanath, B., M.S. Chandra, H. Pallavi, and B.R. Reddy. 2008. Screening and assessment of laccase producing fungi isolated from different environmental samples. Afr J Biotechnolog. 7.

Vivekanand, V., P. Dwivedi, N. Pareek, and R.P. Singh. 2011. Banana peel: a potential substrate for laccase production by Aspergillus fumigatus VkJ2. 4.5 in solid-state fermentation. App biochem biotechnolog. 165:204 https://doi.org/10.1007/s12010-011-9244-9

Wahab, A.M., B. Zeshan, N. Ahmed, M. Afzal, and M. Naveed. Molecular Survey of Campylobacter jejuni in Broiler Chicken Farms in East Coast of Peninsular, Malaysia. Pak $\quad J \quad$ Zool. 2021 . https://dx.doi.org/10.17582/journal.pjz/20180702090700

Xin, F., and A. Geng. 2011. Utilization of horticultural waste for laccase production by Trametes versicolor under solid-state fermentation. App biochem biotechnolog. 163:235-246. https://doi.org/10.1007/s12010-010-9033-x 